\title{
TERAPI PSIKORELIGI DALAM MENINGKATKAN KESEHATAN PASIEN
}

\author{
Nur Hidaayah \\ Fakultas Keperawatan dan Kebidanan \\ Universitas Nahdlatul Ulama Surabaya, Jln. Smea 57 Surabaya \\ Email : nurhid@unusa.co.id
}

\begin{abstract}
Priority problem of clients who are hospitalized are vulnerable to anxiety and tend to get depressed, so this ailment affects the healing process. Lying weak clients who will feel saturated, thinking negatively about the condition of hers that never improved thus will lower the body's immunity, increases the suffering of the impact a slowdown in the process of adaptation and healing. Psikoreligi therapy is given in the form of guidance on the concept of healthy hospitals from the viewpoint of religion, guidance for dhikr and prayer.Individuals who have spiritual health, life becomes more sincere or resignation towards everything that is given by God, so that will happen the process homeostasis (balance). All protectors are there in the human body working with the obedience of worship, more closer to Allah SWT and clever grateful so created an atmosphere of balance of neurotransmitters in the brain.
\end{abstract}

Keywords: psycoreligi, health, patient

Abstrak : Permasalahan utama klien yang dirawat di rumah sakit sangat rentan mengalami rasa cemas dan cenderung mengalami rasa tertekan hingga depresi. Kondisi kritis ini dapat berpengaruh terhadap penurunan imunitas tubuh meningkatkan penderitaan yang berdampak menurunnya proses adaptasi dan penyembuhan penyakitnya. Tenaga kesehatan dalam hal ini perawat dan dokter dapat menjadi pendukung kesembuhan pasien melalui terapi psikoreligi. Pemberian terapi ini meliputi bimbingan tentang konsep sehat-sakit dari sudut pandang agama, bimbingan untuk berdzikir dan berdoa. Individu yang mempunyai kesehatan spiritual, hidup menjadi lebih ikhlas atau pasrah terhadap segala sesuatu yang diberikan oleh Allah, sehingga akan terjadi proses homeostasis (keseimbangan). Semua protektor yang ada didalam tubuh manusia bekerja dengan ketaatan beribadah, lebih mendekatkan diri kepada Allah SWT dan pandai bersyukur sehingga tercipta suasana keseimbangan dari neurotransmiter yang ada di dalam otak.

Keywords: psikoreligi, kesehatan, pasien

\section{PENDAHULUAN}

Permasalahan utama klien yang dirawat di rumah sakit sangat rentan mengalami rasa cemas dan cenderung mengalami rasa tertekan hingga depresi. Kondisi kritis ini dapat berpengaruh terhadap penurunan imunitas tubuh meningkatkan penderitaan yang berdampak menurunnya proses adaptasi dan penyembuhan penyakitnya (Putra, S.T, 2011).

Dimensi spiritual berupaya untuk mempertahankan keharmonisan atau keselarasan dengan dunia luar, berjuang untuk menjawab atau mendapatkan kekuatan ketika sedang menghadapai stress emosional, penyakit fisik, atau kematian. Kekuatan yang timbul diluar kekuatan manusia (Kozier,Erb,Blais \& Wilkinson, 1995; Murray \&Zentner,1993 cit Hamid 2000 dalam Fitriah 2015). Keterkaitan antara spiritualitas, kesehatan dan sakit yaitu keyakinan spiritual sangat penting bagi perawat karena dapat mempengaruhi tingkat kesehatan dan perilaku perawatan diri klien.Beberapa pengaruh dari keyakinan spiritual sebagai berikut yaitu menuntun kebiasaan hidup 
sehari-hari, sumber dukungan, sumber kekuatan dan penyembuhan, sumber konflik (Hamid (2000), dalam Fitriah 2015).

Manusia sebagai makhluk ciptaan Tuhan, telah diwajibkan untuk beribadah kepada Allah SWT. Kita terkadang tidak menjalankan secara maksimal atau khusyuk karena sangat lemah iman, merasa waktu kita terbatas dan bahkan menyalahkan situasi yang tidak mendukung. Terapi psikoreligi jika dilaksanakan secara maksimal akan menjadi tindakan yang efektif menurunkan gangguan penyakit bahkan gangguan jiwa sekalipun (Sulistyowati, Prihantini, 2015).

Menurut Taylor, Lillis \& Le Mone (1997) dan Craven \& Hirnle (1996), faktor penting yang dapat mempengaruhi spiritualitas seseorang adalah pertimbangan tahap perkembangan, keluarga, latar belakang etnik dan budaya, pengalaman hidup sebelumnya, krisis dan perubahan, terpisah dari ikatan spiritual, isu moral terkait dengan terapi, asuhan keperawatan yang kurang sesuai (Fitriah, 2015).

Terapi Psikoreligi merupakan tindakan penanganan pada klien dengan memakai upaya pendekatan psikologi dan spiritual melalui cara mendekatkan diri kepada Allah SWT. Terapi psikoreligi ini dapat diaplikasikan melalui kegiatan ritual keagamaan, seperti sholat, membaca dan mengkaji Al Qur'an, berdoa, dzikir (memanjatkan pujian), membaca buku agama serta mendengarkan ceramah keagamaan. Semua hal tersebut dilakukan dengan melibatkan sisi psikologis manusia yaitu kekhusyukan saat melakukannya (keyakinan, harapan, ketakutan kepada Allah SWT, tujuan dan arti hidup).Doa doa dalam dimensi psikoreligius, doa berarti permohonan penyembuhan kepada Tuhan Yang Maha Esa.Sedangkan dzikir adalah mengingat
Tuhan dengan segala kekuasaan-Nya, mengucapkan baik secara lisan maupun dalam hati segala kuasa-Nya. Dari sudut ilmu keperawatan jiwa atau kedokteran jiwa atau kesehatan jiwa, doa dan dzikir (psikoreligius terapi) merupakan terapi psikiatrik setingkat lebih tinggi daripada psikoterapi biasa.

\section{METODE}

Metode yang digunakan dalam
penyusunan artikel tentang terapi
psikoreligi dalam meningkatkan kesehatan klien ini adalah studi literatur, yaitu penulis terlebih dahulu meninjau permasalahan yang menjadi issue di dunia kesehatan (tempat pelayanan kesehatan), selanjutnya penulis membaca beberapa literatur terkait di tambah beberapa penemuan dari hasil penelitian dan yang telah dilakukan sebelumnya artikel yang kemudian menyusun laporan artikel ini berdasarkan templet yang telah ditetapkan dalam jurnal ilmiah kesehatan.

\section{HASIL DAN PEMBAHASAN}

1. Hasil penelitian

Berdasarkan hasil penelitian yang dilakukan oleh Saseno (2014) yang dilakukan di Panti Sosial Tresna Werdha Abiyoso Yogjakarta yaitu membandingkan antara kelompok kontrol dan kelompok eksperimen dengan hasil bahwa nilai $Z$ sebesar -4.638 lebih kecil dari nilai $Z$ pada tabel, dengan demikian terapi psikoreligius efektif terhadap penurunan tingkat depresi pada lansia (Saseno, Arifah S, 2014).

Menurut penelitian yang dilakukan Sulistyowati dan Prihantini, pada tahun 2015 bahwa terapi psikoreligi terhadap penurunan perilaku kekerasan, respon fisik, respon verbal dan respon emosi pada pasien skizofrenia yang di rawat di Rumah Sakit Jiwa Daerah Surakarta.

Sedangkan penelitian yang dilakukan oleh Wakhidah, Umrotul 
(2016) tentang Pengaruh terapi psikoreligi terhadap penurunan skala insomnia pada pasien hemodialisadi RSUD Semarang, mendapatkan hasil bahwa, sebagian besar (64,7\%) responden hanya mengalami insomnia ringan setelah mendapatkan terapi psikoreligi.

\section{Pembahasan}

Berdasarkan uraian beberapa hasil penelitian diatas, bahwa perawat sebagai petugas kesehatan dalam menjalankan asuhan keperawatannya perlu melakukan pengkajian spiritual pada pasien dan keluarganya. Penemuan data subyektif yang meliputi konsep Tuhan dan keTuhanan, selanjutnya darimana sumber harapan dan kekuatan, apa saja praktik agama dan ritual yang biasa dilakukan pasien dan keluarga, serta bagaimana hubungan keyakinan dengan kondisi kesehatan saat ini (Yosep I, Sutini, 2014). Kemudian data tersebut didukung oleh observasi yang menghasilkan data obyektif meliputi afek (nada perasaan) dan sikap pasien dan keluarga terhadap penyakitnya, pola perilaku yang nampak melalui verbal (ungkapan perasaan), fisik (menolak diobati atau tidak mau diberi pertolongan) serta hubungan pasien dan keluarga maupun lingkungan sekitarnya (Jauhari, J, 2014).

Beberapa metode yang bisa digunakan dalam memberikan terapi psikoreligi antara lain Anonymous (2014) :

a. Metode Wawancara

Merupakan komunikasi dua arah secara pribadi untuk mendapatkan fakta kejiwaan tentang kebiasaan keagamaan yang dilakukan pasien. Data ini akan dicatat secara rinci dan runut di buku catatan pasien dan disimpan secara baik. Buku ini akan digunakan kembali saat dibutuhkan. Catatan pribadi pasien ini bisa di analisa dan diidentifikasikan kemudian digunakan sebagai bahan pertimbangan perawat atau dokter dalam penggunaan metode terapi psikoreligi yang diberikan akan lebih tepat. Cara ini banyak digunakan oleh petugas kesehatan di tempat pelayanan kesehatan. b. Metode Berkelompok

Merupakan cara pembinaan jiwa melalui kegiatan keagamaan secara berkelompok seperti pertemuan dan diskusi, seminar, ceramah dan acara lainnya. Metode ini dapat berjalan lancar jika didukung lingkungan yang tenang, nyaman, jumlah kelompok tidak terlalu besar dan pembahasan materi yang sangat terkait.

c. Metode Edukatif

Yaitu pasien menyampaikan perasaan tertekan kepada perawat sampai tuntas, kemudian diakhiri dengan memberi motivasi dan meyakinkan pasien tentang harapan hidupnya.

d. Metode Direktif

Metode ini lebih bersifat mengarahkan pasien untuk berusaha mengatasi problema yang dialami. Perawat bersifat aktif memberikan solusi dari kesulitan pasien.

e. Metode Non Direktif

Perawat bersifat pasif hanya mendengarkan, penuh kesabaran namun aktif menganalisa hambatan dalam kesuksesan pasien mencapai hal yang diinginkan.

Selanjutnya perawat dan atau dokter dapat menetapkan tindakan yang akan dilakukan yaitu (Yusuf A, et al, 2017) :

a. Nilai keyakinan spiritual pribadi petugas terlebih dahulu.

b. Fokus pikiran pada persepsi klien akan kebutuhan spiritualnya.

c. Yakinkan diri bahwa klien sangat membutuhkan spiritual.

d. Ketahui kesan nonverbal klien yang mencerminkan kebutuhan spiritual.

e. Berespon secara singkat terhadap ungkapan verbal, sikap dan perilaku klien.

f. Jadilah pendengar yang aktif dan sabar. 
g. Miliki rasa empati terhadap penderitaan pasien.

h. Kenali respon awal saat terjadi depresi

i. Bantu pasien menemukan hikmah dari penderitaannya.

j. Yakinkan bahwa pasien dapat memenuhi kebutuhan spiritualnya.

k. Berikan respon etik \& konflik yang dialami (antisipasi hal yang tidak perlu dilakukan perawat, agar pasien tetap percaya kepada perawat).

1. Berikan dukungan apapun keputusan pasien untuk menerapkan nilai hidupnya.

m. Sediakan tempat khusus saat pasien membutuhkan untuk kegiatan spiritualnya.

n. Tambahkan kegiatan rutin keagamaan seperti mendengar ceramah agama, buku spiritual, sholat malam, dan sebagainya.

Perawat dapat mengukur keberhasilan tindakan yang dilakukan dengan pernyataan verbal pasien dan kemampuan observasi, meliputi adanya :

1. Peningkatan spiritual pasien dan keluarga

2. Citra diri yang kuat $\&$ realistis

3. Hubungan interpersonal yang terbuka \& hangat

4. Mempertahankan misi dalam hidup

5. Meraih kembali harapan hidup

Harapan akhir yang ingin dicapai setelah melakukan terapi psikoreligi ini adalah, pasien mampu : beristirahat dengan tenang, menyatakan menerima keputusan moral atau etika, mengungkapkan rasa tenang dan dalam di hati saat berhubungan dengan Allah SWT, menunjukkan hubungan yang hangat dan terbuka dengan pemuka agama, menunjukkan afek yang positif tanpa rasa marah, bersalah dan ansietas, menunjukkan perilaku lebih positif, mengekspresikan arti positif terhadap situasi dan keberadaannya (Hamid, A.Y, 2008).

\section{SIMPULAN}

Simpulan yang dapat diambil berdasarkan penjelasan diatas bahwa pasien dan keluarga yang akan diberikan terapi psikoreligi perlu :

1. Dikaji tentang konsep keTuhanan, harapan dan kebiasaan keagamaan yang dilakukan, sikap, perilaku serta keadaan sakitnya.

2. Petugas kesehatan (perawat atau dokter) mendampingi pasien saat melakukan ritual keagamaan akan menambah tingkat keberhasilan terapi.

3. Perlunya kerjasama interdisiplin dalam melakukan terapi psikoreligi. Evaluasi hasil yang didapat pasien salah satunya adalah peningkatan kesehatan. Terapi psikoreligi dapat diterapkan pada pasien dengan berbagai kasus penyakit. Rumah sakit dapat menfasilitasi terapi ini dengan menyediakan pembimbing rohani (Ustadz) yang bekerjasama dengan perawat, dokter dan tenaga kesehatan lainnya. Terapi psikoreligi menjadi salah satu keahlian perawat yang dikuasai melalui mata kuliah keperawatan jiwa dan Agama.

\section{DAFTAR PUSTAKA}

Anonymous. (2014). BAB II TERAPI PSIKORELIGIUS DAN NARKOBA. repository.umy.ac.id/bitstream/handle/ 123456789/11473/6.\%20BAB\%20II.p df?. diakse tanggal 20 Agustus 2017.

Fitria, N. (2015). Terapi Psikospiritual Sebuah Hasil Penelitian. https://nitafitria.wordpress.com/2009/0 2/09/terapi-psikospiritual-sebuahhasil-penelitian/. Diakses tanggal 20 Agustus 2017.

Hamid, A.Y. (2008). Bunga Rampai Asuhan Keperawatan Kesehatan Jiwa. Penerbit EGC. Jakarta. 
Jauhari, J. (2014). Skripsi :Pengaruh Terapi Psikoreligius : Doa Dan Dzikir Terhadap Penurunan Tingkat Depresi Pada Penderita Gagal Ginjal Kronik Yang Menjalani Hemodialisa Di Ruang Hemodialisa Rumah Sakit Kota Semarang 2014. artikel\%20jurnal\%20psikoreligi/peran $\% 20$ psikoreligi\%20utk\%20menurunka n\%20depresi\%20pd\%20pasien\%20G GK.pdf. Diakses tanggal : 20 Agustus 2017.

Putra, S.T. (2011). Psikoneuroimunologi Kedokteran. Pusat penerbitan dan percetakan Universitas Airlangga. Surabaya.

Saseno, Arifah S. (2014) Jurnal Keperawatan Jiwa . Volume 2, No. 1 : Efektivitas Terapi Psikoreligius Terhadap Penurunan Tingkat Depresi Lansia Di Panti Sosial Tresna Werdha Abiyoso Sleman Yogyakarta. ppnijateng.org/.../11.-Efektifitas-

Terapi-Psikoreligius-terhadappenurunan-tingkat-Depresi lansia. Diakses tanggal : 20 Agustus 2017

Sulistyowati, Prihantini. (2015). Jurnal Terpadu Ilmu Kesehatan Volume 4 Nomer 1 : Pengaruh Terapi Psikoreligi Terhadap Penurunan Perilaku Kekerasan Pada Pasien Skizofrenia Di Rumah Sakit Jiwa Daerah Surakarta. Artikel\%20jurnal\%20psikoreligi/peng aruh\%20psikoreligi\%20terhadap\%20pe nurunan\%20PK.PD F. Diakses tanggal : 20 Agustus 2017.

Yosep I, Sutini (2014). Buku Ajar Keperawatan JIwa. Penerbit Refika Aditama. Bandung.

Yusuf A, et al. (2017). Kebutuhan Spiritual: Konsep dan Aplikasi dalam Asuhan Keperawatan. Penerbit Mitra Wacana Media. Jakarta.

Wakhidah, Umrotul (2016). Thesis : Pengaruh Terapi Psikoreligi Terhadap Penurunan Skala Insomnia pada PasienYang Menjalani Hemodialisa di RSUD
Repository.unissula.ac.id/4609/. Diakses tanggal 5 September 2017 